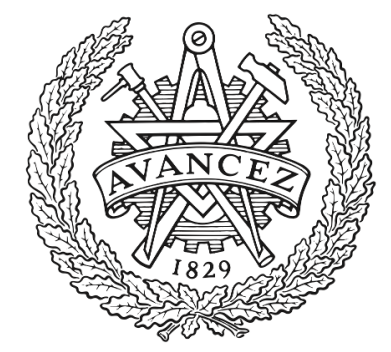

CHALMERS

UNIVERSITY OF TECHNOLOGY

\title{
Effects of construction industry support for PhD projects: The case of a Swedish scheme
}

Downloaded from: https://research.chalmers.se, 2023-04-26 13:24 UTC

Citation for the original published paper (version of record):

Bröchner, J., Sezer, A. (2020). Effects of construction industry support for PhD projects: The case of a Swedish scheme. Industry \& higher education, 34(6): 391-400.

http://dx.doi.org/10.1177/0950422220904932

N.B. When citing this work, cite the original published paper. 


\section{Effects of construction industry support for PhD projects: The case of a Swedish scheme}

Industry and Higher Education 2020, Vol. 34(6) 391-400 (C) The Author(s) 2020

Article reuse guidelines: sagepub.com/journals-permissions DOI: 10.1 I 77/0950422220904932 journals.sagepub.com/home/ihe

\author{
Jan Bröchner $\mathbb{D}^{\mathbb{D}}$ and Ahmet Anıl Sezer \\ Chalmers University of Technology, Sweden
}

\begin{abstract}
One of the many varieties of university-industry collaboration is industry engagement in doctoral programmes. A scheme operated by the Development Fund of the Swedish Construction Industry since the early 1990s has supported thesis projects for about $150 \mathrm{PhD}$ candidates. While they were doctoral students they were employed by contractors as industrial doctoral candidates or by universities. The purpose of this investigation was to analyse how, as PhD graduates, they perceived the benefits of doctoral studies for themselves as individuals and also how they have contributed to the organization that employs them. Results from a survey with 125 respondents show that the greatest individual benefit is that of being able to access relevant information more rapidly, and that the greatest perceived organizational benefit arises from their ability to cooperate with knowledgeable clients.
\end{abstract}

\title{
Keywords \\ Construction, PhD programmes, Sweden, university-industry relations
}

One of the many varieties of university-industry collaboration (Sjöö and Hellström, 2019) is industry engagement in doctoral programmes (Thune, 2009), and in particular when firms support what are known as industrial $\mathrm{PhD}$ candidates, implying that the $\mathrm{PhD}$ candidates remain as industry employees while pursuing their doctoral studies. Alternatively, industry may sponsor, through project grants, at least part of the work on a thesis project regardless of the nature of the employer. Today, these mechanisms are operative in a number of countries and industries, including construction. While such arrangements have been the subject of earlier investigations, it has seldom been possible to compare the effects of having undertaken doctoral-level education as a university or industry employee. Knowledge of such effects is needed as it concerns the individual development of skills, which may influence recruitment to doctoral programmes, and also in the context of explaining to corporate management how the internal presence of $\mathrm{PhDs}$ provides a range of potential benefits.

Research collaboration between the construction industry and universities has been studied as a special case by Bossink (2004) and for construction engineering by Lucko and Kaminsky (2016). Collaboration is seen as one way of achieving construction innovations (Bröchner and
Lagerqvist, 2016; Shapira and Rosenfeld, 2010). While construction research might not be fully typical of the science, technology, engineering, and mathematics (STEM) field, partly because of the service element in what construction contractors deliver, it is an advantage to be able to analyse data from a single field such as construction and a single country (Sweden). This disciplinary and geographical focus keeps a number of contextual factors that interact with the disciplinary mechanism (Moghadam-Saman, 2019) almost constant.

A construction industry scheme for supporting $\mathrm{PhD}$ thesis projects has functioned since the early 1990s in Sweden and offers an opportunity to study the effects of such measures. The Development Fund of the Swedish Construction Industry (SBUF) was created by industry confederations and unions in 1983 and concentrated on development projects during its first decade (Bröchner and Grandinson, 1992). SBUF can be seen as an industry intermediary with the function of an innovation broker (Winch and Courtney,

\section{Corresponding author:}

Jan Bröchner, Department of Technology Management and Economics, Chalmers University of Technology, SE-41296 Göteborg, Sweden.

Email: jan.brochner@chalmers.se 
2007). After a 1991 initiative by construction employers, SBUF inaugurated a scheme to support $\mathrm{PhD}$ thesis projects in the four major universities with graduate construction programmes. A research committee was set up to review grant applications, which are submitted through member contractors and not directly from university researchers. The annual grant volume is about MSEK 30, corresponding to about 3 million euro.

The purpose of this investigation was to analyse how construction-oriented $\mathrm{PhD}$ graduates have perceived the benefits of doctoral studies for themselves as individuals and also how they have contributed to the organization that employs them. The specific objectives were:

(1) to compare the research topics, later employment category and gender effects of industry-based and university-employed doctoral students;

(2) to identify patterns of perceived effects on personal development;

(3) to identify patterns of perceived effects on the profitability of the employing organization; and

(4) to compare patterns for male and female $\mathrm{PhD}$ graduates.

The article begins with a review of earlier literature on industry-supported $\mathrm{PhD}$ programmes in various disciplines and in construction in particular. Next, the background and principles of the Swedish support scheme are presented, followed by the survey methodology. The findings are then reported and discussed, leading to conclusions that include strategic options for both firms and universities when developing their construction-oriented $\mathrm{PhD}$ programmes.

\section{Earlier studies}

There is a rapidly growing number of studies on collaborative university-industry $\mathrm{PhD}$ projects and programmes in general, mostly concerned with European and Australian experiences (Roberts, 2018). These studies should be seen against the background of the variety of scientific disciplines and industries. Compared to the engineering discipline in general, researchers in construction technology tend to rely more on contract research and less on personal mobility between universities and industry, according to Schartinger et al. (2002) in their Austrian investigation. Their survey revealed that the construction industry interacted with universities in a pattern resembling that for business services, although construction was much more dependent on joint research; still, when comparing manufacturers of motor vehicles with construction firms, the latter were less engaged in joint research projects. This should be noted, since there is some evidence that prior engagement with universities encourages firms to recruit $\mathrm{PhD}$ graduates (Garcia-Quevedo et al., 2012).

\section{Organizing collaborative $\mathrm{PhD}$ programmes}

Doctoral students in science and engineering tend to engage in more collaboration with firms and public organizations than those in other disciplines, regardless of the type of programme (Bienkowska and Klofsten, 2012). In an early review of the literature on collaborative $\mathrm{PhD}$ arrangements, Thune (2009) concluded that researchers had mostly looked at what the $\mathrm{PhD}$ candidates had experienced and their situation while still at university and in their later careers. Denmark has been one of the pioneers of government-supported industrial $\mathrm{PhD}$ programmes (Kolmos et al., 2008), and Norway introduced government support in 2008 for an industry $\mathrm{PhD}$ scheme, with an interview survey indicating that the students had little difficulty in matching the demands of the university and of the firms with which they interacted (Thune, 2010). The panEuropean DOC-CAREERS study of collaborative programmes has identified a range of working practices and supporting policy measures, stressing the need for more knowledge on career pathways (Borrell-Damian et al., 2010). Collaboration is not always harmonious, as indicated by Grimm (2018) in her case study of a German programme with the automobile industry. A typical hybrid scheme is that for semi-industrial $\mathrm{PhD}$ students, who work in research centres with close industrial contacts (Granata and Dochy, 2016). Such collaborative doctoral programmes based on centres have been developed in Australia (Manathunga et al., 2012) and the United Kingdom (Kitagawa, 2014).

Another hybrid approach is for industrial $\mathrm{PhD}$ candidates to have office space at both their industry employer's premises and their university, as is often the case in Sweden (Kihlander et al., 2011). The main focus of PhD programmes in Sweden is the dissertation and, although the programmes are research-based, there is an important element of taught courses during the 5 years that are typical at Swedish technical universities. Collaboration with industry can be through industrial $\mathrm{PhD}$ students who are employed by an organization or through industry funding for university-employed $\mathrm{PhD}$ students.

Analysing survey responses concerning almost 200 joint $\mathrm{PhD}$ projects at Eindhoven University of Technology in the Netherlands, Salimi et al. (2016) found that management decisions, supervision and communication characteristics had a significant effect on the success of a project. For industrial $\mathrm{PhD}$ students with both university and industry advisors, Roolaht (2015) emphasizes the need to develop the role and support of the industry advisors.

\section{Developing personal skills}

In Sweden, $\mathrm{PhD}$ candidates in engineering are often employed for a 5 -year period by their university, which includes engagement in teaching for $20 \%$ of their time. In 
many European $\mathrm{PhD}$ programmes, courses in theory and methodology dominate the coursework element, and a 2007 survey in Norway indicated that only $20 \%$ of technology $\mathrm{PhD}$ candidates aimed to work in a university or a higher education college (Kyvik and Olsen, 2012). If we turn to doctorate holders, about $75 \%$ of them thought that their expectations had been fulfilled to a large degree. Kyvik and Olsen (2012) also investigated in their survey how $\mathrm{PhD}$ holders perceived the relevance of generic skills obtained in doctoral training, but these data were not presented separately for the technology field. However, considering only those $\mathrm{PhD}$ graduates who were employed outside academic institutions and research institutes, the highest benefits were reported for 'training in systematic/ analytic thinking' and 'training in handling complex problems' (but these also received the highest scores for those employed in academic institutions). On the other hand, when asked which elements their doctoral training should have emphasized more, the top skill in demand was 'project planning', followed by 'insights into research management' for those working outside academia.

There is a longer tradition of studying how generic skills are added or reinforced by higher degrees (Gilbert et al., 2004). While there have been studies of industry's views on graduate competencies (Pang et al., 2019), and specifically for construction graduates (Ahn et al., 2012), less is known about the competencies added by doctoral training.

There have been earlier studies of research schools in Sweden, beginning with the interviews conducted by Wallgren and Dahlgren (2007). It is in the context of research schools that prior works are found concerning the effects of $\mathrm{PhD}$ students' engagement with industry on corporate performance. A study of three engineering doctoral schools, based on collaboration between industry and academia, identified five outcomes for participating firms: competence, new and/or developed products and processes, strengthened relationships with academia, new and strengthened contacts with other companies and legitimacy (Assbring and Nuur, 2017). There are also impacts from such schools on universities and regional development (Gustavsson et al., 2016). The skills and knowledge needed for research careers in industry have been analysed in Belgium by De Grande et al. (2014). They studied five clusters, one of which was in engineering, and distinguished between 27 skills. Skills need assessments were made by employers and by the doctoral candidates themselves. Project management skills were clearly ranked higher by employers than by the PhD students; the importance of social skills was overestimated by the students in comparison to the views of employers. In a Norwegian survey (Thune and Børing, 2015), the focus was on how innovation competencies in firms were developed by means of industry-PhD projects. About 130 responses from innovating firms revealed that their strongest motivations for engaging in such collaborative projects were: (i) to increase the competitiveness of the firm; (ii) to increase the firm's competence in the field of interest of the industrial $\mathrm{PhD}$ candidate; (iii) because the project was related to the core competence of the firm; and (iv) the project would increase the innovation capability of the firm.

There have been few investigations into how $\mathrm{PhD}$ candidates (Horta, 2018) and $\mathrm{PhD}$ degree holders (Lee et al., 2010; Platow, 2012) themselves perceive the skill effects of their studies. Lee et al. (2010) asked University of Manchester $\mathrm{PhD}$ graduates in science and engineering about the usefulness of seven competences. The answers depended on their career type: those who held technical positions in manufacturing ranked problem-solving capability highest, whereas application of information technology came lowest on the scale. There is difficulty, however, in achieving high response rates for investigations in this field, and they tend to include a broad range of disciplines.

\section{Gender aspects}

Earlier studies of women with a $\mathrm{PhD}$ in engineering have considered how the proportion of female graduates has developed and the effects of how the field of studies is defined, and have also compared career patterns in academia and industry. In many countries, women are underrepresented among engineering doctoral graduates; an OECD survey reported that $21 \%$ of these graduates were female (Auriol, 2010: 9). The US Survey of Earned Doctorates in 2006 indicated that female PhDs in Civil Engineering constituted $17.7 \%$ of all $\mathrm{PhDs}$ in the field, and that this figure had increased markedly since 1996 (Hoffer et al., 2007); this trend continues (NSF, 2018). Redefining and broadening the field as Civil and Environmental Engineering, indicating a stronger link to humanitarian aims, has contributed to a higher proportion of female PhDs at one US university (Posselt et al., 2018). Judging by data from Spain, there is a gender aspect with regard to how civil engineering PhDs are paid (Canal-Domínguez and Wall, 2014) and how easily they find relevant employment (Domínguez and Gutiérrez, 2015). A comparison of careers for doctorate holders in four European countries reveals that national contexts are associated with important differences (Duarte and Mendonça, 2016). Analysing employment patterns for PhDs from two major European universities of technology, Conti and Visentin (2015) found that female $\mathrm{PhD}$ graduates were more likely to be working in administration or holding positions in universities rather than in non-R\&D-intensive companies.

\section{Method}

This investigation is based on existing records and a questionnaire sent to $\mathrm{PhD}$ graduates whose dissertation projects had been financed at least partly by SBUF grants. SBUF has kept records on all supported $\mathrm{PhD}$ theses. A time limit 
was set in order to ensure that respondents had at least about 3 years of work experience after receiving their $\mathrm{PhD}$ degree. Based on this criterion, 148 potential respondents were found who had defended their theses between 1991 and 2014. With very few exceptions, their degrees were awarded by the four Swedish universities of technology that offer construction engineering programmes. According to data from the Swedish Higher Education Authority (UKÄ), the annual number of PhDs awarded in the broad field of the Built Environment, which includes Civil Engineering, Architecture and Transportation Engineering, has varied between 60 and 80 in recent years. Of all 349 fulltime equivalent $\mathrm{PhD}$ students in this field in Sweden in $2011,10.6 \%$ were industry-employed and $55.8 \%$ held $\mathrm{PhD}$ candidate positions at their university. These aggregated data indicate that about one civil engineering $\mathrm{PhD}$ in four received financial support from SBUF.

Background information on all survey individuals was collected through SBUF records, company and professional association databases as well as LinkedIn. Data included respondents' thesis defence year, gender, thesis topic (categorized as infrastructure, building materials, building construction, HVAC, information technology, quality management, environmental and related to occupational health and safety [OSHA], management and business relations and maintenance), employer (contractor, small consultant, large consultant, other company, association, public agency, university, research institute), university awarding the degree, present country of residence and email address.

\section{The questionnaire}

The questionnaire was developed from the literature review. A first draft was modified after discussion with members of the SBUF research committee. The final questionnaire had five main questions. The first served to clarify the respondent's original $\mathrm{PhD}$ status group: whether they had been employed by a university or a company ('industrial $\mathrm{PhD}$ ') during their dissertation project. It should be mentioned that, with very few exceptions, all respondents had been formally awarded the Swedish Tekn.dr degree, which is usually translated as a $\mathrm{PhD}$ and not as a specific vocational-type degree. The next question asked how long they had stayed with the same employer after receiving their degree, and the third question was about their current occupation.

Question 4 included nine statements concerning perceived effects on the profitability of the organization where the respondent was employed. These statements were primarily derived from questionnaires developed by De Grande et al. (2014), Thune and Børing (2015) and Assbring and Nuur (2017). The nine effects included finding solutions to urgent technical problems, collaboration with other industries, increasing efficiency in the organization and supporting digitalization in the organization. Question 5 covered nine personal development topics and asked to what extent the thesis project had influenced the respondent as an individual. Here, the personal development topic statements were formulated relying on earlier questionnaires developed by Lee et al. (2010), Kyvik and Olsen (2012) and again by De Grande et al. (2014). The six personal development topics included: 'helped me to get a holistic view', 'helped me to split problems into subproblems to be solved by others', 'made me quicker to obtain relevant knowledge', 'strengthened my self-confidence and made me feel secure in my professionalism', 'improved my linguistic ability and presentation skills in public' and 'created a social network for me including other disciplines'. Replies to questions 4 and 5 were recorded on a continuous scale of 1-100 instead of a traditional Likert-type scale.

\section{Data collection and analysis}

The questionnaire was sent by email to the 148 potential respondents in October 2017, using SurveyMonkey, followed by two reminders. This online survey was closed at the end of October and resulted in 108 responses. In order to increase the response rate, the questionnaire was sent as a Word document to non-respondents, attached to individual emails, in the following month. To four individuals who had indicated technical problems, the questionnaire was sent as a postal survey. It was found that three PhDs had passed away and that a few had retired. In total, 125 doctorate holders returned the questionnaire, corresponding to an $86.2 \%$ response rate. Numerous individual comments were received and supported the interpretation of results. The independent samples $t$-test was used to compare different groups: (i) $\mathrm{PhDs}$ who defended their theses in 1991-2004 and in 2005-2014, (ii) male and female PhDs and (iii) $\mathrm{PhDs}$ employed in industry and $\mathrm{PhDs}$ employed in a university.

\section{Results}

\section{Background data for the PhDs}

Table 1 shows background information for all who had obtained their PhD degree up to the end of 2014 ( $N=$ 145 ), derived from publicly accessible records. In order to identify time trends, data are also shown for two time periods, 1991-2004 and 2005-2014. The outcome of the $t$-test comparing respondents who defended their theses during these two periods showed that their dissertation topics differed significantly for two topics: building materials $(p=0.009, t=2.631)$ and management and business relations $(p=0.01, t=2.618)$. It is clear that after 2005 the percentage of thesis projects focusing on infrastructure and building materials drops, while the percentage of those dealing with building construction and management business relations increases. As to employers, consultancy 
Table I. Data for PhDs, 199I-2004 and 2005-20I4.

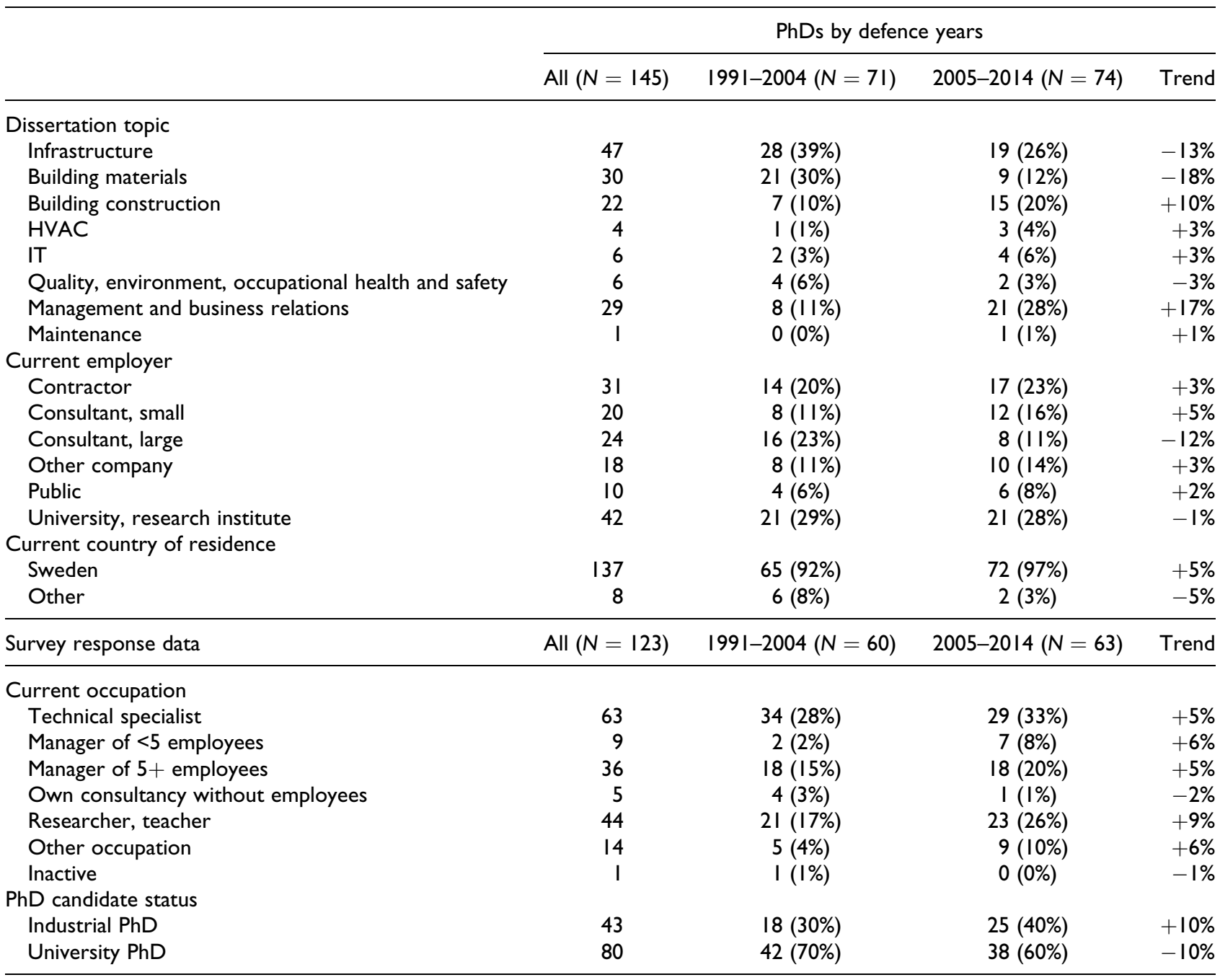

firms were divided into two categories according to size, with 'small consultants' being those with fewer than 10 employees. The $t$-test for respondents' employers indicated lower significance, with respondents working for large consultants coming out highest ( $p=0.058, t=1.910$ ). However, as can be seen from Table 1 , the percentage of PhDs working today for small consultants appears to increase after 2005 while there is a noticeable decrease in the percentage of PhDs working for larger consultants. Overall, more than half the PhDs are employed today by a university, a research institute, a consultant or a contractor. The 'other occupation' category includes PhDs working in the manufacturing industry, non-construction IT consultants and government non-construction agencies. No homemakers were identified, and nearly all respondents were active.

Based on incomplete data, it seems that those supported by SBUF typically received their $\mathrm{PhD}$ degree in their early 30s. This also means that those who received their degrees in the early years of the programme were about 60 years of age when responding, although some respondents were in a higher age group. Very few PhDs were employed outside Sweden, and the majority of those who had moved were to be found in Norway.

Overall, the majority $(81 \%)$ of dissertations between 1991 and 2014 were defended by males, with $19 \%$ defended by females. However, the average $\mathrm{PhD}$ defence year is later for women, implying that their proportion increased over time. In order to compare dissertation topic and current employers of male and female $\mathrm{PhDs}$, the independent samples $t$-test was again used. The dissertation topics of these two groups differed significantly for infrastructure ( $p=0.022, t=2.308)$; quality, environment, occupational safety and health $(p=0.05, t=1.957)$; and maintenance ( $p=0.041, t=2.067)$. While infrastructure and building materials were the main topics explored by 
Table 2. Data for PhDs, male and female.

\begin{tabular}{lcc}
\hline & \multicolumn{2}{c}{ PhDs by gender } \\
\cline { 2 - 3 } & Male & Female \\
& $(N=117)$ & $(N=28)$ \\
\hline PhD defence year (mean) & 2004 & 2006 \\
Dissertation topic & & \\
Infrastructure & $43(37 \%)$ & $4(14 \%)$ \\
Building materials & $25(21 \%)$ & $5(18 \%)$ \\
Building construction & $16(14 \%)$ & $6(21 \%)$ \\
HVAC & $4(3 \%)$ & 0 \\
IT & $6(5 \%)$ & 0 \\
Quality, environment, occupational & $3(3 \%)$ & $3(11 \%)$ \\
$\quad$ safety and health & & \\
Management and business relations & $20(17 \%)$ & $9(32 \%)$ \\
Maintenance & 0 & $1(4 \%)$ \\
Current employer & & \\
Contractor & $27(23 \%)$ & $4(14 \%)$ \\
Consultant, small & $17(15 \%)$ & $3(11 \%)$ \\
Consultant, large & $22(19 \%)$ & $2(7 \%)$ \\
Other company & $11(9 \%)$ & $7(25 \%)$ \\
Public & $7(6 \%)$ & $3(11 \%)$ \\
University, research institute & $33(28 \%)$ & $9(32 \%)$ \\
Current country of residence & & \\
Sweden & $111(95 \%)$ & $26(93 \%)$ \\
Other & $6(5 \%)$ & $2(7 \%)$ \\
\hline
\end{tabular}

male PhDs, management and business relations and building construction were preferred by females. Employment patterns of male and female PhDs differed significantly only for 'other company' as employer $(p=0.025, t=$ 2.273). The largest differences in employment patterns are that male PhDs tend to work more often in consultancy firms and that female PhDs are more often to be found in the category of 'other company' (see Table 2).

There is no important difference in the gender of the $\mathrm{PhDs}$ between the two $\mathrm{PhD}$ status groups (see Table 3, where 'University $\mathrm{PhD}$ ' refers to those who were university employees when studying for their PhD). However, the defence year averages for male and female $\mathrm{PhDs}$ indicate that the percentage of industrial $\mathrm{PhDs}$ increased over the years. Here, the $t$-test results revealed that dissertation topics did not differ significantly between industrial $\mathrm{PhDs}$ and university PhDs. A clear difference between the two groups is that industrial PhDs' theses focused on management and business relations far less frequently. Here, it should be noted that SBUF does not operate with a detailed programme of topic priorities, which means that the dissertation topic patterns in Table 1 reflect outcomes of dialogues between university researchers, potential $\mathrm{PhD}$ candidate and contractor members of SBUF. Industrial and university PhDs' current employers differed significantly for contractors $(p=0.007, t=2.744)$ and university, research institutes ( $p=0.014, t=2.488)$. The results show that those who were employed by their university as $\mathrm{PhD}$ candidates are mostly employed today by universities or a research institute, while contractors are the main employer of the industrial PhDs.

As Table 3 also shows, around one-third of PhDs work today as technical specialists. Note that the sum for all occupations exceeds 123 , since respondents were allowed to indicate more than one single occupation. The $t$-test for the current occupation of PhDs shows that industrial and university $\mathrm{PhDs}$ differ significantly only in the case of managers responsible for at least five employees $(p=0.002, t=3.182)$. The greatest differences between the two groups are that (i) one-third of industrial PhDs work as managers responsible for at least five employees, while the corresponding percentage drops to $14 \%$ for those who had been university-employed $\mathrm{PhD}$ candidates, and (ii) the percentage of those who had been university-employed as candidates and who now work as researchers or teachers is clearly higher than for the industrial PhDs. Nevertheless, one in five of the industrial PhDs is a researcher or teacher today. The item response rate was less than half for the question concerning how long the $\mathrm{PhD}$ had stayed with the employer who had employed them during the PhD programme, and it is probable that the question had been formulated such that it was misunderstood by many respondents.

\section{Effects of a PhD on personal development and employer}

Respondents in general assigned an average of 88 (on the 1-100 scale) to the statement that it had been worth the effort to study for a PhD. Two high scores for effects were given by respondents for the statements that doing a $\mathrm{PhD}$ had made them quicker to obtain relevant knowledge $(88$ out of 100) and had helped them to get a more holistic view (87), while the lowest score (70) was for the statement that the PhD had led to the creation of a social network. According to the $t$-test for effects of a $\mathrm{PhD}$, industrial and university-employed $\mathrm{PhDs}$ ranked only the 'made me quicker to obtain relevant knowledge' statement significantly differently ( $p=0.021, t=2.337)$. With one exception, 'my $\mathrm{PhD}$ degree was worth the effort', those who had been university-employed as $\mathrm{PhD}$ candidates reported slightly higher scores for all statements than did the industrial PhDs (see Table 4). Standard deviations are also indicated for each statement.

A total of 78 respondents chose to assess nine potential effects of their PhD degrees on the profitability of their organization - in most cases, the firm employing them. Of these, 29 were industrial PhDs. The $t$-test failed to indicate significant differences between industrial and university-employed PhDs. The respondents ranked collaborating with knowledgeable clients as well as planning and implementing $\mathrm{R} \& \mathrm{D}$ projects as constituting the highest 
Table 3. Industrial and university PhDs.

\begin{tabular}{|c|c|c|c|c|c|}
\hline & \multicolumn{5}{|c|}{ PhDs candidate status } \\
\hline & \multirow{2}{*}{$\begin{array}{c}\text { All } \\
(N=123)\end{array}$} & \multicolumn{2}{|c|}{ Industrial PhD $(N=43)$} & \multicolumn{2}{|c|}{ University $\mathrm{PhD}(\mathrm{N}=80)$} \\
\hline & & Male $(N=35)$ & Female $(N=8)$ & Male $(N=64)$ & Female $(N=16)$ \\
\hline PhD defence year (average) & 2004 & 2006 & 2007 & 2003 & 2006 \\
\hline \multicolumn{6}{|l|}{ Dissertation topic } \\
\hline Infrastructure & 41 & 13 & 1 & 25 & 2 \\
\hline Building materials & 22 & 7 & I & 10 & 4 \\
\hline Building construction & 21 & 5 & 1 & 10 & 5 \\
\hline HVAC & 3 & 1 & 0 & 2 & 0 \\
\hline IT & 6 & 3 & 2 & 3 & 0 \\
\hline $\begin{array}{l}\text { Quality, environment, occupational safety and } \\
\text { health }\end{array}$ & 5 & I & 2 & I & I \\
\hline Management and business relations & 24 & 4 & 3 & 13 & 4 \\
\hline Maintenance & 1 & 0 & 1 & 0 & 0 \\
\hline \multicolumn{6}{|l|}{ Current employer } \\
\hline Contractor & 31 & 15 & 2 & 12 & 2 \\
\hline Consultant, small & 12 & 2 & I & 8 & I \\
\hline Consultant, large & 20 & 6 & 1 & 12 & 1 \\
\hline Other company & 15 & 4 & 2 & 5 & 4 \\
\hline Public & 8 & 2 & 1 & 3 & 2 \\
\hline University, research institute & 37 & 5 & 2 & 24 & 6 \\
\hline \multicolumn{6}{|l|}{ Current occupation } \\
\hline Technical specialist & 64 & 16 & 3 & 37 & 8 \\
\hline Manager of $<5$ employees & 9 & 2 & 1 & 3 & 3 \\
\hline Manager of $5+$ employees & 36 & 18 & 2 & 15 & 1 \\
\hline Own consultancy without employees & 5 & 1 & 0 & 4 & 0 \\
\hline Researcher, teacher & 44 & 8 & 3 & 27 & 6 \\
\hline Other occupation & 13 & 2 & 2 & 6 & 3 \\
\hline Inactive & 1 & 0 & 0 & I & 0 \\
\hline \multicolumn{6}{|l|}{ Current country of residence } \\
\hline Sweden & 115 & 32 & 8 & 60 & 15 \\
\hline Other & 8 & 2 & 1 & 4 & I \\
\hline
\end{tabular}

Table 4. Effects of the $\mathrm{PhD}$ degree on personal development, $\mathrm{I}-100$ scale values.

\begin{tabular}{|c|c|c|c|c|c|c|}
\hline \multirow[b]{3}{*}{ Statement } & \multicolumn{6}{|c|}{ PhD candidate status } \\
\hline & \multicolumn{2}{|c|}{$\begin{array}{c}\text { All } \\
(N=123)\end{array}$} & \multicolumn{2}{|c|}{$\begin{array}{l}\text { Industrial PhD } \\
\quad(N=43)\end{array}$} & \multicolumn{2}{|c|}{$\begin{array}{c}\text { University PhD } \\
\quad(N=80)\end{array}$} \\
\hline & Mean & SD & Mean & SD & Mean & SD \\
\hline Made me quicker to obtain relevant knowledge & 88 & 13 & 85 & 15 & 90 & 11 \\
\hline Helped me to get a more holistic view & 87 & 16 & 84 & 19 & 88 & 13 \\
\hline Increased my linguistic ability and ability to present in public & 85 & 17 & 84 & 18 & 86 & 16 \\
\hline Strengthened my self-confidence, confident in my professionalism & 83 & 19 & 79 & 22 & 85 & 17 \\
\hline Better at splitting problems into subproblems to be solved by others & 79 & 22 & 78 & 20 & 79 & 23 \\
\hline Created a social network for me including other disciplines & 70 & 24 & 66 & 24 & 72 & 23 \\
\hline My $\mathrm{PhD}$ degree was worth the effort & 88 & 20 & 91 & 18 & 87 & 21 \\
\hline
\end{tabular}

Note: SD: standard deviation.

effects, while supporting digitalization in the organization was assigned the lowest scale value (see Table 5).

The extent, on average, to which the abilities they obtained during their $\mathrm{PhD}$ helped to improve their organization's profitability can also be analysed based on time trends, with 40 respondents having defended their theses between 1991 and 2004 while 38 defended them between 2005 and 2014. For all statements, older PhDs 
Table 5. Perceived effects of $\mathrm{PhD}$ on organizational profitability, $1-100$ scale values.

\begin{tabular}{|c|c|c|c|c|c|c|}
\hline \multirow[b]{3}{*}{ Statement } & \multicolumn{6}{|c|}{$\mathrm{PhD}$ candidate status } \\
\hline & \multicolumn{2}{|c|}{ All $(N=78)$} & \multicolumn{2}{|c|}{ Industrial $\mathrm{PhD}(\mathrm{N}=29)$} & \multicolumn{2}{|c|}{ University $\mathrm{PhD}(\mathrm{N}=49)$} \\
\hline & Mean & SD & Mean & SD & Mean & SD \\
\hline Collaborate with knowledgeable clients & 79 & 22 & 78 & 21 & 78 & 21 \\
\hline Plan and implement R\&D projects & 78 & 25 & 75 & 25 & 80 & 24 \\
\hline Act as a research supervisor, mentor & 71 & 30 & 69 & 30 & 71 & 28 \\
\hline Identify and collaborate with foreign experts & 70 & 26 & 69 & 29 & 70 & 24 \\
\hline Attract new employees, for example, by supervising MSc theses & 67 & 28 & 70 & 27 & 64 & 27 \\
\hline Find solutions to urgent technical problems & 67 & 28 & 62 & 23 & 68 & 30 \\
\hline Increase the efficiency of the organization & 64 & 25 & 67 & 23 & 60 & 24 \\
\hline Collaborate with other industries & 61 & 27 & 57 & 27 & 62 & 27 \\
\hline Support digitization in the organization & 45 & 29 & 47 & 26 & 43 & 30 \\
\hline
\end{tabular}

Note: SD: standard deviation.

ranked the effects of their $\mathrm{PhD}$ on the profitability of their organization higher, the difference ranging from 3 to 19 , again on the 1-100 scale, with the sole exception of 'supporting digitalization in the organization' which received a four units higher value from the more recent PhDs. The largest gap between the two groups (with 19 units) is for the statement of 'acting as a research supervisor, mentor', followed by two other statements (with a gap of 13 units) 'increasing the efficiency of the organization' and 'identifying and collaborating with foreign experts'. The smallest gap between the two groups, only three units on the scale, is for the statement about collaborating with knowledgeable clients.

A further analysis of pairwise correlations between statements concerning personal development and those concerning effects on organizational profitability failed to indicate strong ties, although it would be reasonable to expect a relationship between, for example, 'holistic view' and 'collaborate with knowledgeable clients'. The highest Pearson correlation (0.38) was between 'better at splitting problems into subproblems' and 'collaborate with other industries'. Highest (0.38) among the correlations between statements related only to personal development effects was that between 'more holistic view' and 'better at splitting problems into subproblems'. The highest correlation (0.45) between 'my $\mathrm{PhD}$ degree was worth the effort' and personal development effects was with 'more holistic view'. Among the statements relating only to organizational effects, the highest correlation (0.64) was between the scale values for 'increase the efficiency of the organization' and 'collaborate with knowledgeable clients'.

\section{Discussion and conclusions}

Currently, in many countries, there are schemes for basing doctoral studies on collaboration between industry and universities. The Swedish example analysed here represents a long-term commitment by construction contractors to support $\mathrm{PhD}$ programmes through project grants to doctoral students. Unlike most doctoral fellowship programmes with industry support, the SBUF scheme focuses on selecting dissertation projects that are to be awarded grants. In this context, the recruitment of $\mathrm{PhD}$ candidates is formally a university task, and the selection of candidates is in most cases done with active participation from an SBUF member firm, not by the Fund itself. The intermediary role of the Fund implies that the proportion of female PhDs who receive support is an outcome of policies pursued by universities and member firms.

The questionnaire was sent to two categories of PhDs industrial $\mathrm{PhDs}$ who were employed in industry when studying for their degree and those who had held $\mathrm{PhD}$ candidate positions in universities. The response rate was unusually high for a survey of this type and should ensure reliability of the career data and reported opinions on how doctoral study had developed individual skills and contributed to the organization for which the respondents were currently working. Findings from the present survey show that it is clearly a misconception to think that construction $\mathrm{PhDs}$ are narrow specialists confined to their original dissertation topic. The respondents emphasized that their $\mathrm{PhD}$ education had increased their ability to obtain knowledge and also to view problems in a holistic setting. Many of these PhDs are in managerial positions today, although the single largest occupation is that of technical specialist. There has also been a slow shift in dissertation topics over the years, with management and business relations coming more into focus than in the early days of the SBUF support programme. This is not primarily a consequence of more female $\mathrm{PhD}$ candidates, although these are less attracted by infrastructure topics than their male colleagues. The survey responses imply a need for contractors to raise their ability to retain their female industrial $\mathrm{PhDs}$, who 
currently are more often employed in organizations other than contracting firms.

In general, the long-term career effects of having been an industrial $\mathrm{PhD}$ student are mainly that such graduates are twice as likely as those who had been university-employed $\mathrm{PhD}$ candidates to be employed by a contractor today. On the other hand, a number of industrial $\mathrm{PhDs}$ are employees of universities or research institutes, and some are carrying out other functions in the private and the public sectors. This diversity of employers should not be thought of as a failure of a collaborative $\mathrm{PhD}$ programme; rather, it can be seen as an advantage for contractors that skilled people with a contractor background pursue careers in the wider construction sector. More than has traditionally been the case with manufacturing, close collaboration with customers/owners and suppliers is typical of construction. This is underlined by the perceived close link between the effect of skills for collaborating with knowledgeable clients and increasing the efficiency of the organization in which the $\mathrm{PhD}$ is currently employed. Many of the results from the present study confirm what earlier authors have found, but the emphasis on how $\mathrm{PhD}$ studies strengthen the ability to engage in dialogue with knowledgeable clients is among the new findings.

Two implications for university strategies can be identified. For PhD programmes with taught courses, greater emphasis on elements that reinforce the acquisition of candidate skills that are valued by employers outside academic institutions should be considered. Universities wishing to establish a more balanced gender distribution when recruiting construction $\mathrm{PhD}$ candidates should note that an increased proportion of female candidates has been accompanied by a shift away from narrow technology topics. For both industry and universities, it is worth noting that Swedish experiences indicate that SBUF project grants to $\mathrm{PhD}$ candidates serve as evidence for industry relevance, supporting the award of further grants from government sources. The strategic importance for industry associated with a support scheme for construction $\mathrm{PhD}$ projects is far from limited to the opportunity to employ PhDs skilled in planning and implementing $R \& D$; the commercial effect of the perceived ability to engage with knowledgeable clients is one of the strong points highlighted by the survey respondents.

\section{Declaration of conflicting interests}

The author(s) declared no potential conflicts of interest with respect to the research, authorship and/or publication of this article.

\section{Funding}

The author(s) received no financial support for the research, authorship and/or publication of this article.

\section{ORCID iD}

Jan Bröchner (D) https://orcid.org/0000-0002-1961-0330

\section{References}

Ahn YH, Annie RP and Kwon H (2012) Key competencies for US construction graduates: industry perspective. Journal of Professional Issues in Engineering Education and Practice 138(2): 123-130.

Assbring L and Nuur C (2017) What's in it for industry? A case study on collaborative doctoral education in Sweden. Industry and Higher Education 31(3): 184-194.

Auriol L (2010) Careers of doctorate holders: employment and mobility patterns. OECD Science, Technology and Industry Working Papers, 2010/4, OECD Publishing.

Bienkowska D and Klofsten M (2012) Creating entrepreneurial networks: academic entrepreneurship, mobility and collaboration during PhD education. Higher Education 64(2): 207-222.

Borrell-Damian L, Brown T, Dearing A, et al. (2010) Collaborative doctoral education: university-industry partnerships for enhancing knowledge exchange. Higher Education Policy 23(4): 493-514.

Bossink BA (2004) Managing drivers of innovation in construction networks. Journal of Construction Engineering and Management 130(3): 337-345.

Bröchner J and Grandinson B (1992) R\&D cooperation by Swedish contractors. Journal of Construction Engineering and Management 118(1): 3-16.

Bröchner J and Lagerqvist O (2016) From ideas to construction innovations: firms and universities collaborating. Construction Economics and Building 16(1): 76-89.

Canal-Domínguez JF and Wall A (2014) Factors determining the career success of doctorate holders: evidence from the Spanish case. Studies in Higher Education 39(10): 1750-1773.

Conti A and Visentin F (2015) A revealed preference analysis of PhD students' choices over employment outcomes. Research Policy 44(10): 1931-1947.

De Grande H, De Boyser K, Vandevelde K, et al. (2014) From academia to industry: are doctorate holders ready? Journal of Knowledge Economics 5(3): 538-561.

Domínguez JFC and Gutiérrez CR (2015) Doctoral training and labour market needs: evidence in Spain. Research Evaluation 25(1): 79-93.

Duarte J and Mendonça J (2016) Determinant of careers patterns for doctorate holders. In: Gokhberg L, Shmatko N and Auriol L (eds) The Science and Technology Labor Force: The Value of Doctorate Holders and Development of Professional Careers. Cham: Springer, pp. 193-229.

Garcia-Quevedo J, Mas-Verdú F and Polo-Otero J (2012) Which firms want PhDs? An analysis of the determinants of the demand. Higher Education 63(5): 607-620.

Gilbert R, Balatti J, Turner P, et al. (2004) The generic skills debate in research higher degrees. Higher Education Research and Development 23(3): 375-388. 
Granata S and Dochy F (2016) Applied PhD research in a workbased environment: an activity theory-based analysis. Studies in Higher Education 41(6): 990-1007.

Grimm K (2018) Assessing the industrial PhD: stakeholder insights. Journal of Technology and Science Education 8(4): 214-230.

Gustavsson L, Nuur C and Söderlind J (2016) An impact analysis of regional industry-university interactions: the case of industrial $\mathrm{PhD}$ schools. Industry and Higher Education 30(1): 4151.

Hoffer TB, Hess M, Welch V, et al. (2007) Doctorate Recipients from United States Universities: Summary Report 2006. Chicago: National Opinion Research Centre.

Horta H (2018) PhD students' self-perception of skills and career plans while in doctoral programs: are they associated? Asia Pacific Education Review 19(2): 211-228.

Kihlander I, Nilsson S, Lund K, et al. (2011) Planning industrial $\mathrm{PhD}$ projects in practice: speaking both 'academia' and 'practitionese'. In: DS 68-8: 18th international conference on engineering design (ICED 11): impacting society through engineering design (eds. SJ Culley, BJ Hicks, TC McAloone, et al.), Lyngby/Copenhagen, Denmark, 15-18 August 2011, Vol. 8, pp. 100-109. UK: Design Society.

Kitagawa F (2014) Collaborative doctoral programmes: employer engagement, knowledge mediation and skills for innovation. Higher Education Quarterly 68(3): 328-347.

Kolmos A, Kofoed LB and Du X (2008) PhD students' work conditions and study environment in university- and industry-based $\mathrm{PhD}$ programmes. European Journal of Engineering Education 33(5-6): 539-550.

Kyvik S and Olsen TB (2012) The relevance of doctoral training in different labour markets. Journal of Education and Work 25(2): 205-224.

Lee H, Miozzo M and Laredo P (2010) Career patterns and competences of $\mathrm{PhDs}$ in science and engineering in the knowledge economy: the case of graduates from a UK research-based university. Research Policy 39(7): 869-881.

Lucko G and Kaminsky JA (2016) Construction engineering conference and workshop 2014: setting an industry-academic collaborative research agenda. Journal of Construction Engineering and Management 142(4): 04015096.

Manathunga C, Pitt R, Cox L, et al. (2012) Evaluating industrybased doctoral research programs: perspectives and outcomes of Australian Cooperative Research Centre graduates. Studies in Higher Education 37(7): 843-858.

Moghadam-Saman S (2019) Collaboration of doctoral researchers with industry: a critical realist theorization. Industry and Higher Education 34: 36-49.

NSF (2018) Doctorate recipients from U.S. universities: 2016. Report No. NSF 18-304, National Center for Science and
Engineering Statistics, US National Science Foundation, March.

Pang E, Wong M, Leung CH, et al. (2019) Competencies for fresh graduates' success at work: perspectives of employers. Industry and Higher Education 33(1): 55-65.

Platow MJ (2012) PhD experience and subsequent outcomes: a look at self-perceptions of acquired graduate attributes and supervisor support. Studies in Higher Education 37(1): 103118.

Posselt J, Porter KB and Kamimura A (2018) Organizational pathways toward gender equity in doctoral education: chemistry and civil engineering compared. American Journal of Education 124(4): 383-410.

Roberts AG (2018) Industry and $\mathrm{PhD}$ engagement programs: inspiring collaboration and driving knowledge exchange. Perspectives: Policy and Practice in Higher Education 22(4): 115-123.

Roolaht T (2015) Enhancing the industrial $\mathrm{PhD}$ programme as a policy tool for university-industry cooperation. Industry and Higher Education 29(4): 257-269.

Salimi N, Bekkers R and Frenken K (2016) Success factors in university-industry $\mathrm{PhD}$ projects. Science and Public Policy 43(6): 812-830.

Schartinger D, Rammer C, Fischer MM, et al. (2002) Knowledge interactions between universities and industry in Austria: sectoral patterns and determinants. Research Policy 31(3): 303 328.

Shapira A and Rosenfeld Y (2010) Achieving construction innovation through academia-industry cooperation - keys to success. Journal of Professional Issues in Engineering Education and Practice 137(4): 223-231.

Sjöö K and Hellström T (2019) University-industry collaboration: a literature review and synthesis. Industry and Higher Education 33(4): 275-285.

Thune T (2009) Doctoral students on the university-industry interface: a review of the literature. Higher Education 58(5): $637-651$.

Thune T (2010) The training of 'triple helix workers'? Doctoral students in university-industry-government collaborations. Minerva 48(4): 463-483.

Thune T and Børing P (2015) Industry PhD schemes: developing innovation competencies in firms? Journal of Knowledge Economics 6(2): 385-401.

Wallgren L and Dahlgren LO (2007) Industrial doctoral students as brokers between industry and academia: factors affecting their trajectories, learning at the boundaries and identity development. Industry and Higher Education 21(3): 195-210.

Winch GM and Courtney R (2007) The organization of innovation brokers: an international review. Technology Analysis and Strategic Management 19(6): 747-763. 